\title{
A Model for the Effects of Ethical Work Climate, Organizational Trust and Proactive Customer Services Performance: The Role of Perceived Politicizing in Organization's Reward System
}

Mehdi Yazdanshenas ${ }^{1}$ Assistant Professor, Department of Business Management, Allameh Tabatabaee University, Tehran, Iran (Corresponding Author).

Mostafa Aghaei ${ }^{2}$ M. A., Insurance Management, Allameh Tabatabaee University, Tehran, Iran.

\begin{abstract}
This research aims to investigate the effects of ethical work climate on organizational trust and proactive customer service performance while the mediating role of perceived politicizing in organization's reward system is considered as well. Statistical population consisted of all employees of Pasargad Insurance Company. By applying random sampling method, 260 employees were selected. Data were collected by questionnaires and were analyzed through structural equation modeling. Findings show that ethical work climate has a positive and significant effect on organizational trust and proactive customer services performance and has a negative and significant effect on perceived politicizing in organization's reward system. Results show that perceived politicizing in organization's reward system has a negative impact on organizational trust. Also, findings show that perceived ethical work climate has an indirect effect on organizational trust through perceived politicizing organization's reward system but this indirect effect on proactive customer service performance is not confirmed.
\end{abstract}

Keywords: Organizational Trust, Perceived Ethical Climate, Politicizing the Reward System, Proactive Customer Service Performance, Pasargad Insurance Company.

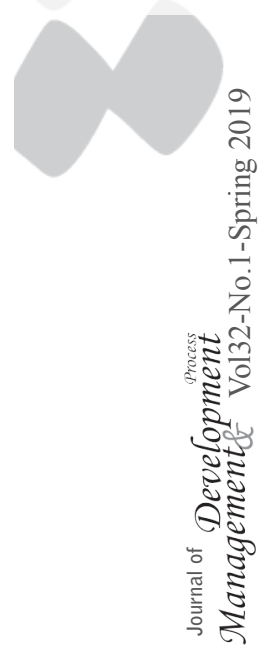

1.yazdanshenas@atu.ac.ir 2. mostafaaghei69@gmail. com 



\section{مقدمه}

تغييرهاى سريع، يكى از ويثزى هاى محيطى است كه سازمانهاى امروزى از جمله شركتهاى بيمه در آن مشغول به فعاليت هستند (Emamgholipour et al., 2017). صنعت بيمه كشور در سالهاى اخير دستخوش تغييرهايى شده است كه زمينهُ ايجاد فضاى رقابتى درون اين صنعت را فراهم ساخته است. خصوصىسازى شركتها و آزادسازى تعرفهها يكى از مهمترين تغييرهايى است كه در صنعت بيمه در سالهاى اخير رخ داده است. خصوصىسازى و آزادسازى به شركتهاى بيمه اين قابليت را دارد كه خدمات متنوعى را با شرايط متفاوت از ديخر شركتها ارائه كنند كه اين امر موجب شكل شيرى فضاى رقابتى بين شركتهاى بيمه مىشود (Altuntas \& Rauch, 2017) . يزوهشهاى اخير بر اهميت رفتارهاى فرانقش كاركنان تاكيد زيادى مى كنند (Bowen, 2016; Griep \& Vantilborgh, 2018). علاوه بر اين، با توجه به اين كه موفقيت سازمانهاى خدماتمحور تا حد زيادى به رفتارهاى كاركنانى كه تعامل مستقيه

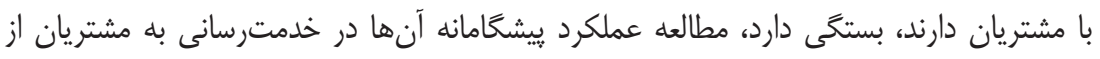
اهميت بسيار زيادى برخوردار است. ضمن اينكه عملكرد خدمترسانى ييشگامانه به مشتريان مفهوم بلنسبت جديدى است كه شناخت عوامل موثر بر آن نيازمند بررسى بيشترى است

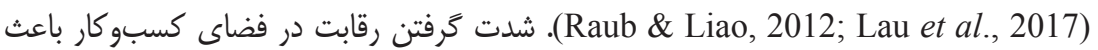
شده است كه همه سازمانها به دنبال كسب مزيتهاى رقابتى باشند تا بتوانند از ديخران در عرصه رقابت ييشى گيرند (Bowen, 2016). بدين منظور، بسيارى از سازمانها بر عوامل سازمانى براى كسب مزيت رقابتى تاكيد دارند (Lee et al., 2012). جوّ كارى اخلاقى ادراكشده يكى از اين عوامل است كه مىتواند در ايجاد روابط بلندمدت با مشتريان بسيار تعيين كننده باشد. مرورى بر ادبيات

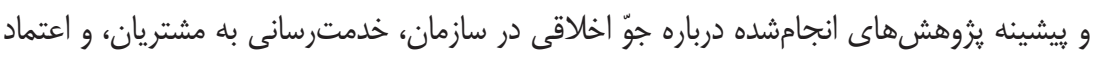
سازمانى نشان مىدهد، سازمانهايى كه به دنبال تعالى در ارائه خدمت به مشتريان و ايجاد اعتماد در سازمان هستند بايد بتوانند خطمشىها و برنامههاى حوزه نيروى انسانى را بهَّونهاى عملياتى نمايند كه ييامدهاى آن بهطور مشخص در ايجاد اعتماد درون سازمان و نيز در رفتارهاى كاركنان در خدمترسانى به مشتريان تجلى يابد (Boon \& Kalshoven, 2014; Hu \& Jiang, 2018). يزوهشهاى ييشين نشان مىدهند كه كاركنان سازمانهايى كه جوّ كارى اخلاقى در آنها حاكم 
است، رفتارهاى مثبت كرايانه بيشترى از خود نشان مىدهند (Adams et al., 2001). اگرجه

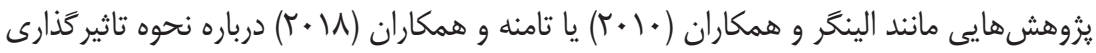
متغيرهاى مديريت منابع انسانى بر رفتارهاى خدمترسانى به مشترى و اعتماد سازمانى انجام

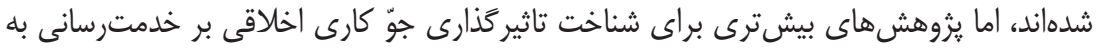

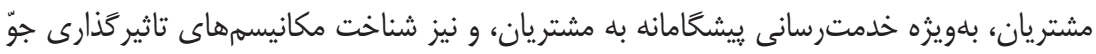

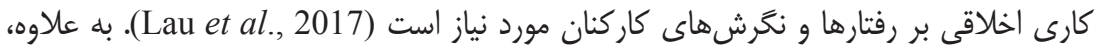

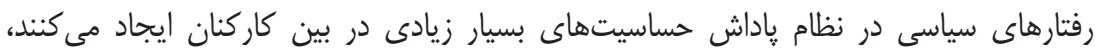

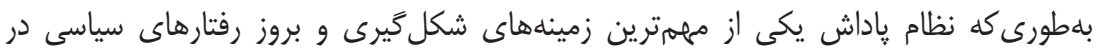
سازمان محسوب مىشود (Gorostidi-Martinez \& Zhao, 2017). بر همين اساس، يزوهش برك

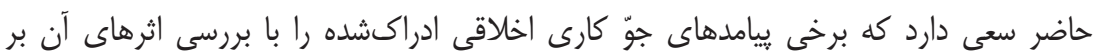

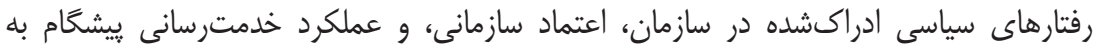

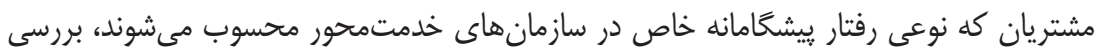

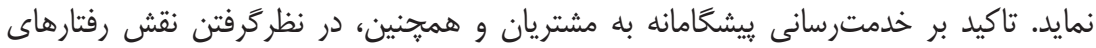

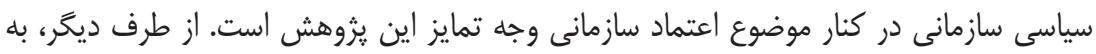

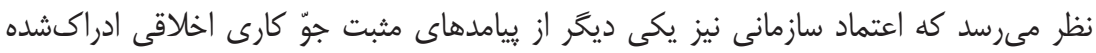

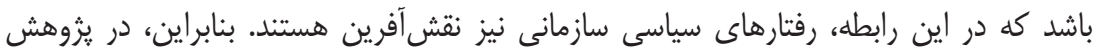

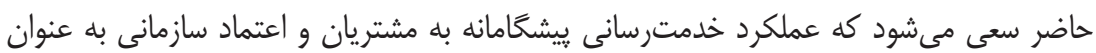

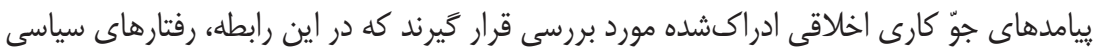

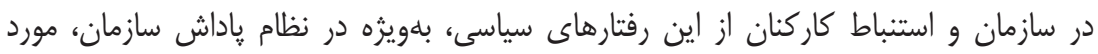

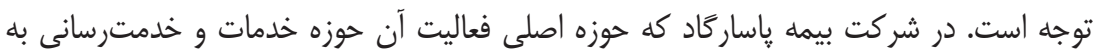

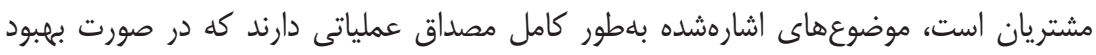

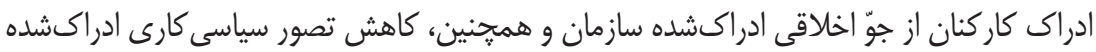

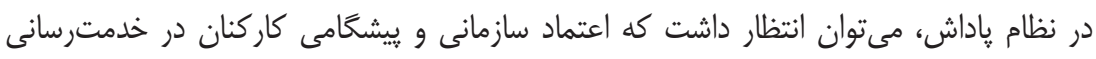

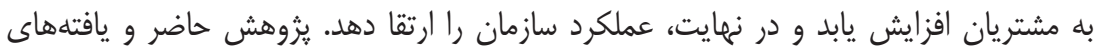

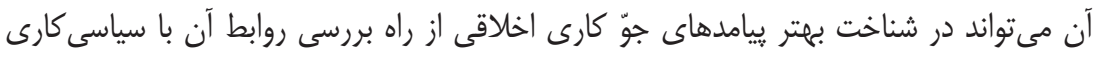

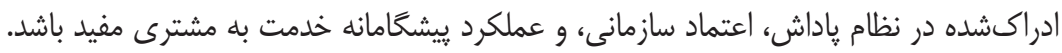




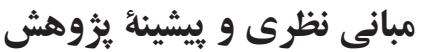

\section{جوّ اخلاقى سازمان}

جوّ اخلاقى سازمان به عنوان ادراكهاى مشترك در مورد اين كه جه هيزى از نظر اخلاقى رفتار

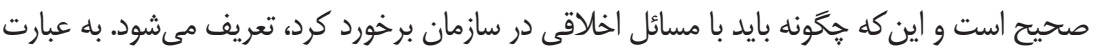

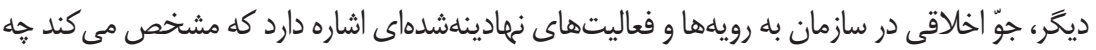
جيزى در سازمان درست و خه جيزى نادرست است (Simha \& Stachowicz-Stanusch, 2015).

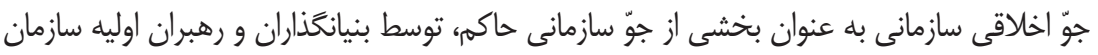

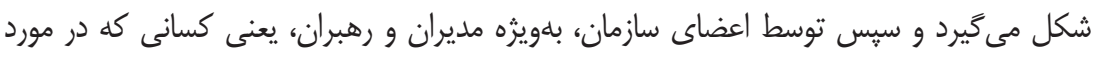
سياستها و قوانين سازمان تصميم مى گيرند، اصلاح و تعديل مىشود (Dickson et al., 2001).

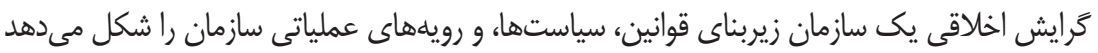

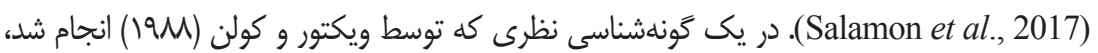

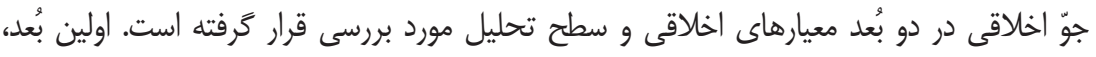

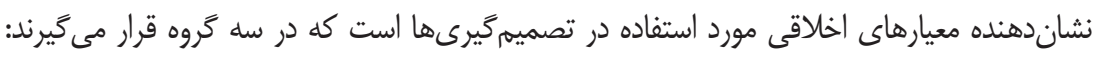

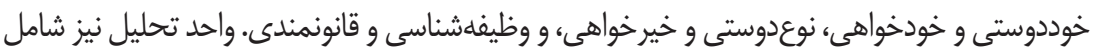

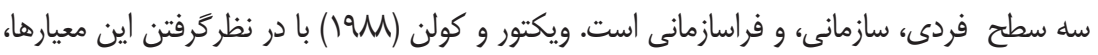

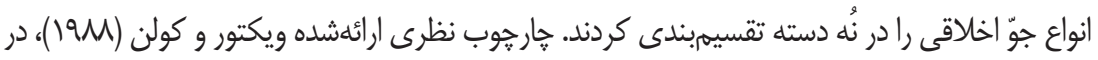

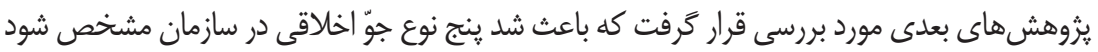

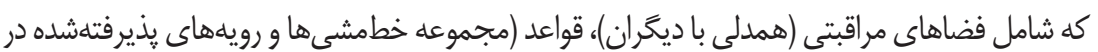
سازمان)، قوانين و مقررات (مقررات رفتارى بذيرفتلشده و قوانين حاكم به وسيله بدنه حرفهاى و نهاد

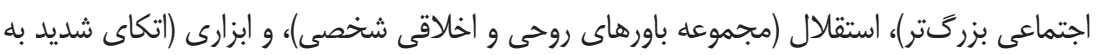

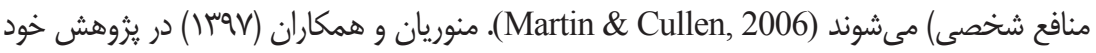
به اين نتيجه رسيدند كه اخلاق كار اسلامى با افزايش رضايت شغلى مىتواند باعث بهببود عملكرد

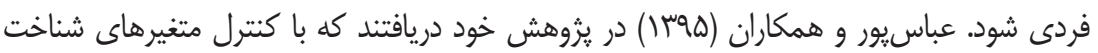

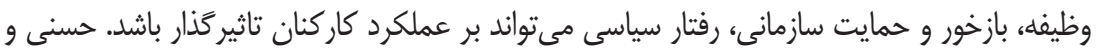
بشيرى (أوجا) در يروهش خود نشان مىدهند كه بين جوّ اخلاقى با رضايت و تعهد كاركنان رابطه

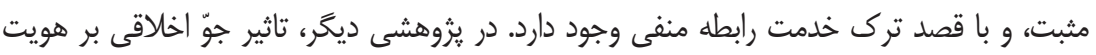

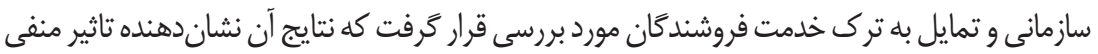

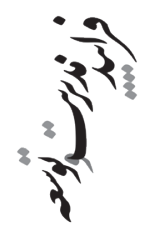




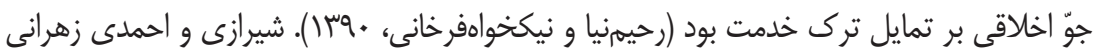

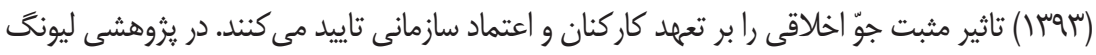

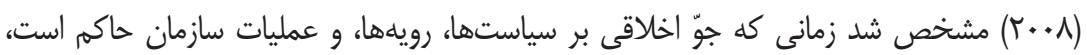

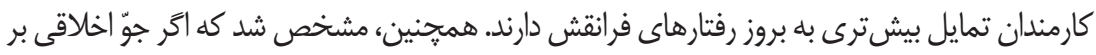

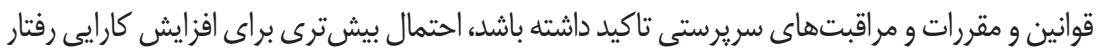

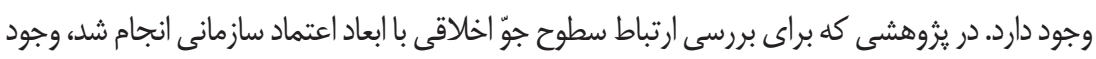

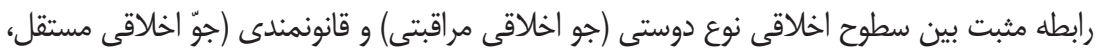

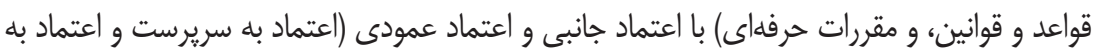

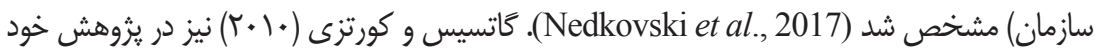

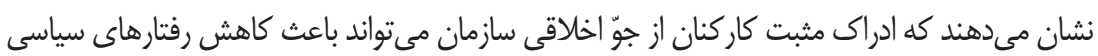
مخرب شود.

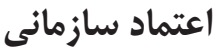

اعتماد عبارت است از اميزان آسيبيذيرى تمايلات و اشتياق يك طرف تعامل با اقدامهاى

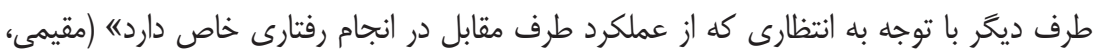

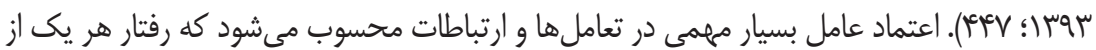

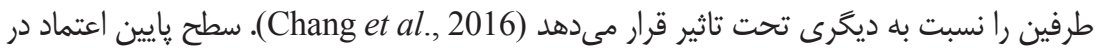

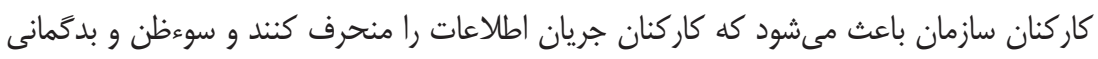

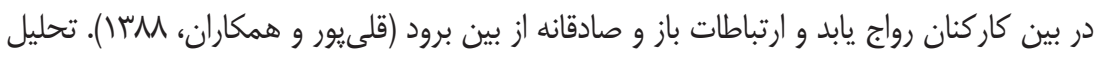

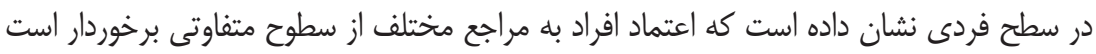
(Fulmer \& Gelfand, 2012) براى مثال، كار كنان ممكن است كه به همكاران اعتماد داشته باشند،

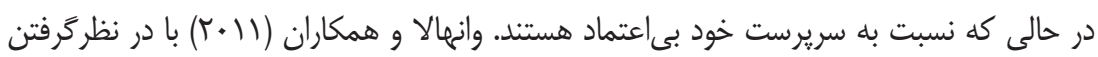

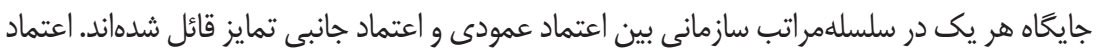

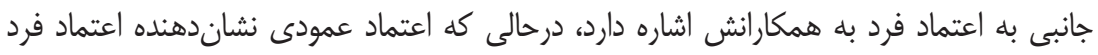

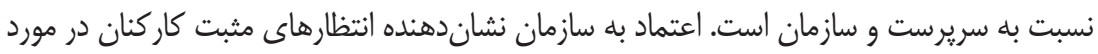
قابليت و عدالت سازمان است (Vanhala et al., 2011). كفتههاى بالا، نشاندهنده لزوم تفكيك سطوح اعتماد در سازمان است. از طرف ديخر، سه جريان اصلى در ادبيات سازمان و مديريت دربار لهاره

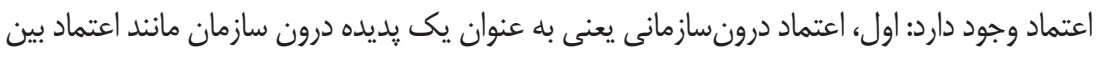


اعضاى سازمان. دوم، اعتماد ميان سازمان ها كه در آن اعتماد به مثابه يك يديده ميانسازمانى مطرح

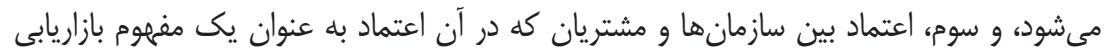

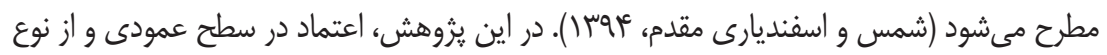
اعتماد درونسازمانى مورد بررسى قرار كرفته است.

\section{عملكرد بيشكامانه خدمت به مشترى}

نبود اطمينان و بىثباتى موجود در فرايند ارائه خدمت به مشترى موجب ابهام در اين فرايند مىشود. بنابراين، ارائه خدمت به مشترى مستلزم ابتكار عمل و ييشنكرىهاى كاركنان در ارائه

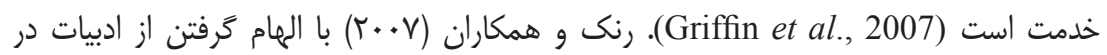
حوزه رفتار سازمانى و با توجه به انواع مختلف رفتارهاى تعاملى كاركنان، اولين كسانى بودند

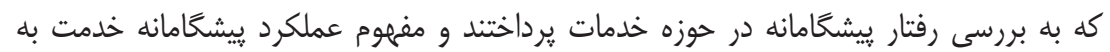

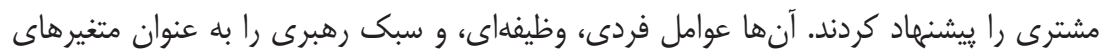

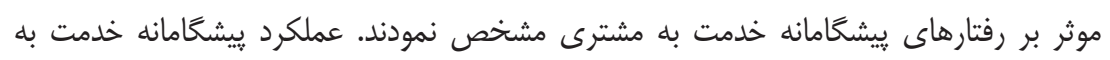
مشترى به عنوان رفتارهاى خودجوش، كرايش بلندمدت، و تفكر روبهجلو براى ارائه خدمت بهان بله مشترى توصيف مىشود (Li et al., 2016). بايد توجه داشت كه اين رفتار، متمايز از وظايف

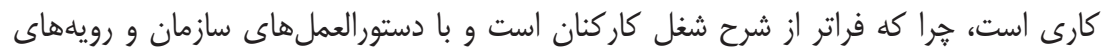

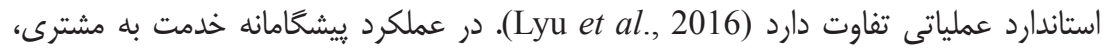

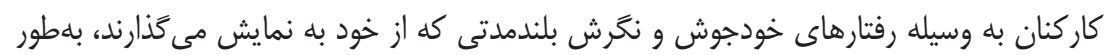

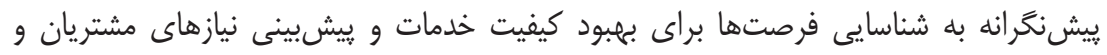

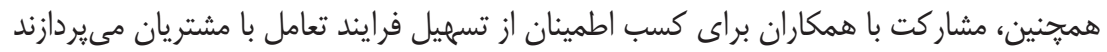

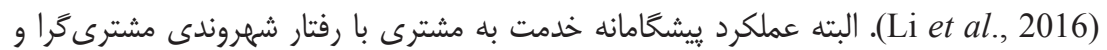
رفتار اجتماعى مشترى كرا تفاوت دارد، هرا كه آنها شامل ابتكار عمل سودمند، تفكرآ آيندهنكر، و و

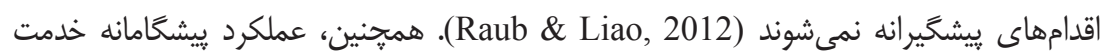
به مشترى، كاركنان را به انجام ابتكار عمل در بهببود فرايندها، يِيشيينى مشكلات آينده، ارائئ راهحلها، و پافشارى در كار دركير مى كند (Grant \& Ashford, 2008).

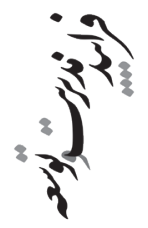




\section{سياسى كارى ادر اكشده در نظام ياداش}

"بروز رفتارهاى سياسى سازمانى بلطور عمومى به عنوان يك فرايند نفوذ اجتماعى تلقى مى شود

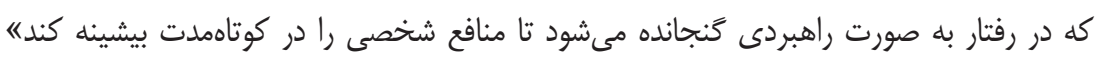

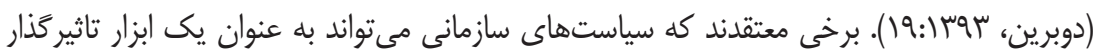

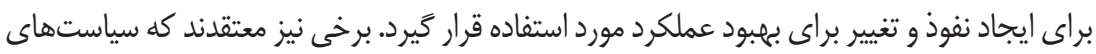
سازمانى، ابزارى براى كسب قدرت و دستيابى به منافع شخصى هستند (دوبرين، سوجسا).

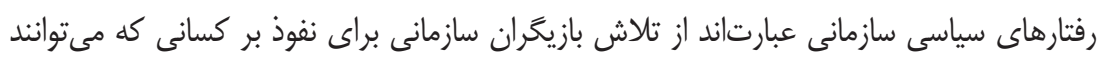

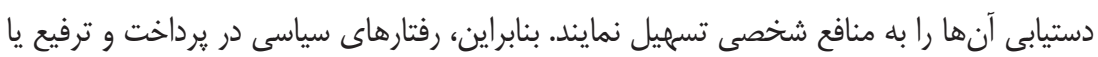

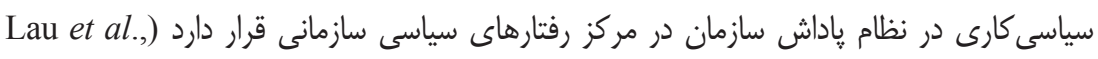

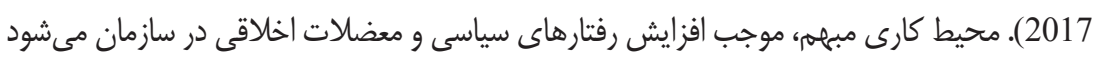

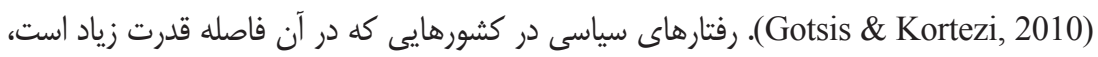

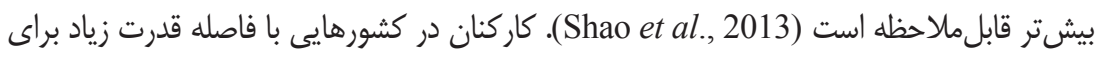

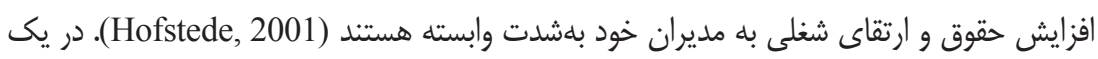

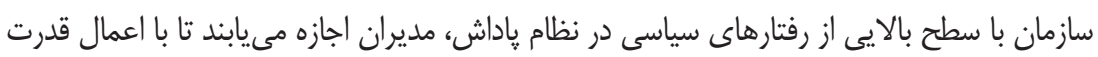

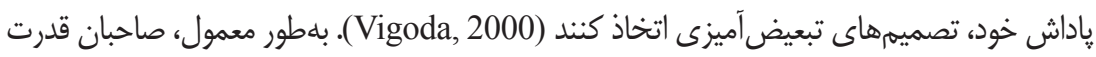

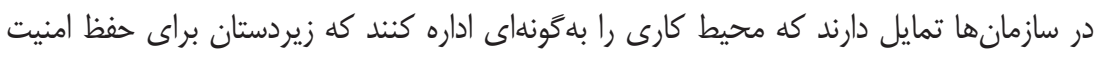

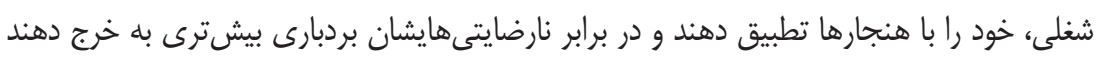

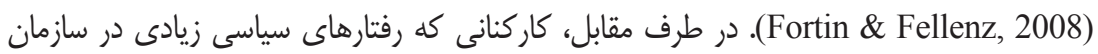

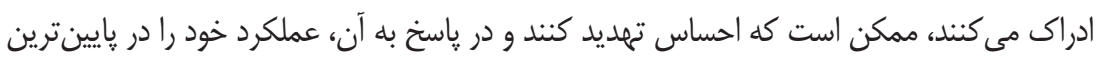

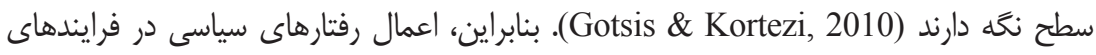

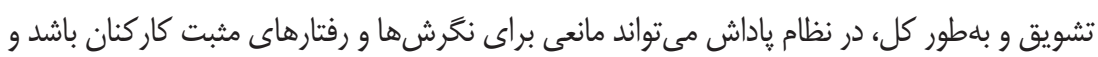
به ساير فعاليتهاى سازمان نيز صدمه بزند (Appelbaum et al., 2005).

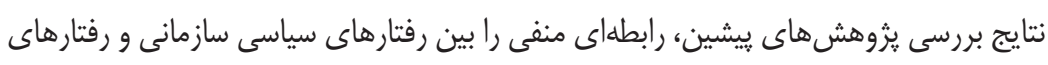

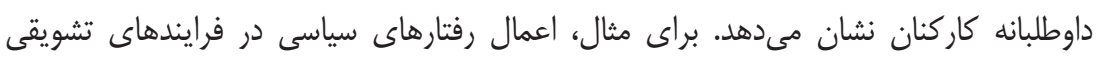

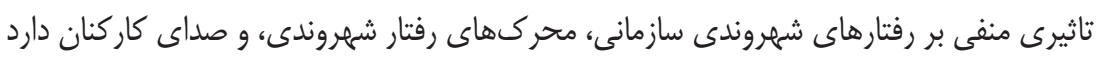

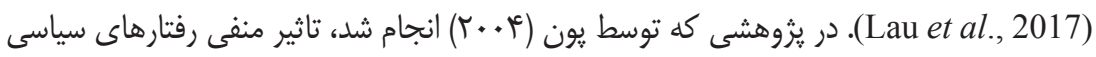

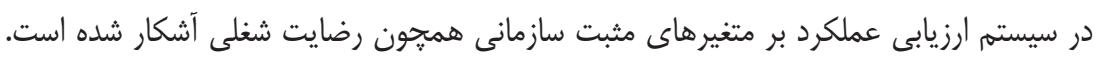
همجنين، ارتباط مثبت رفتارهاى سياسى در سيستم ارزيابى عملكرد با قصد ترك شغل نمائ نمايان شده 
است. همجنين، در يزوهشى كه روسن و همكاران (9. •.ب) انجام دادند، مشخص شد كه ادراك از

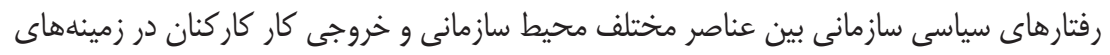

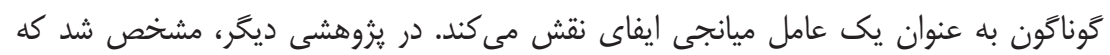
سياسى كارى ادراكشده در نظام ياداش مىتواند باعث كاهش ادراك از عدالت رويهاى شود و در

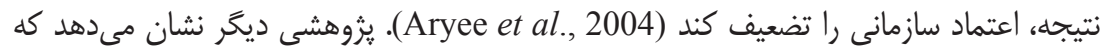
سياسى كارى ادراكشده در نظام پاداش تاثير منفى بر رفتارهاى فرانقش كاركنان برجاى مى كذارداد (Bowler et al., 2010)

اشاره به اين نكته ضرورى است كه ادبيات، نتايج متفاوتى از رفتارهاى سياسى سازمانى را

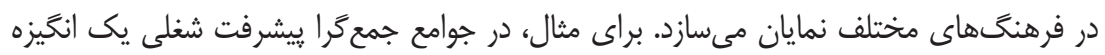

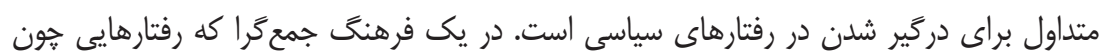

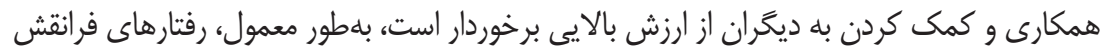

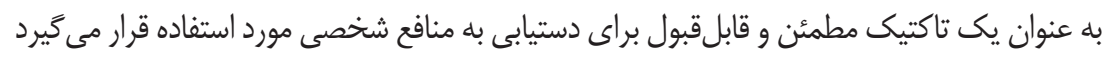

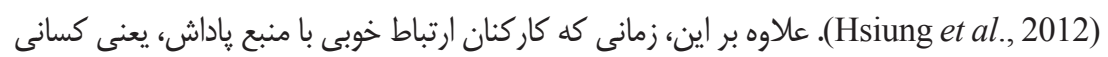

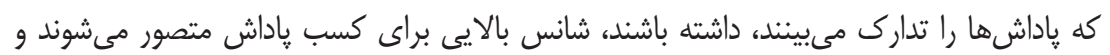

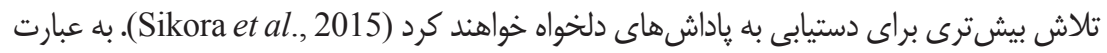

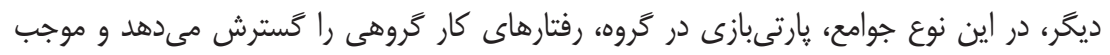

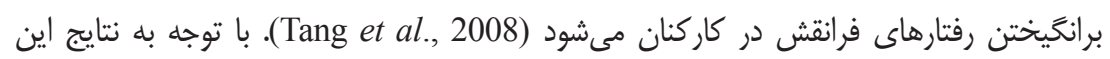

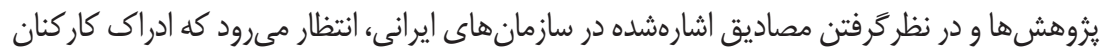

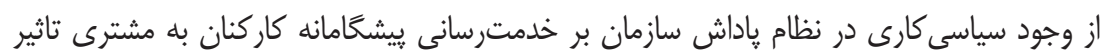
مثبت، و بر اعتماد سازمانى تاثير منفى داشته باشد. از اينرو، فرضيههاى يزوهش به شرح زير تنظيم مىشوند. مدل مفهومى بركَرفته از لائو و همكاران (Y. V) است كه سعى شده است در بستر يك سازمان ايرانى بررسى شود. همجنين، متغيرهاى يزوهش در سطح فردى بررسى مىشوند و ادراك كاركنان از آنها مورد توجه است.

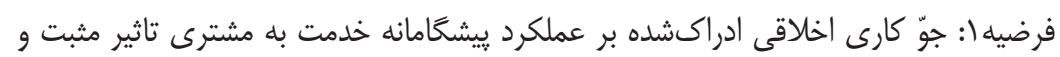

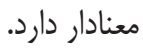

فرضيه ז: جوّ كارى اخلاقى ادراكشده بر اعتماد سازمانى تاثير مثبت و معنادار دارد.

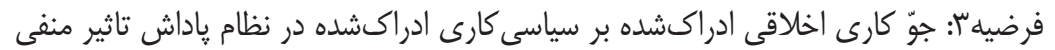
و معنادار دارد. 
فرضيه أ: سياسى كارى ادراكشده در نظام پاداش بر عملكرد يِيشامانه خدمت به مشترى تاثير مثبت و معنادار دارد.

فرضيهه: سياسى كارى ادراكشده در نظام ياداش بر اعتماد سازمانى تاثير منفى و معنادار دارد.

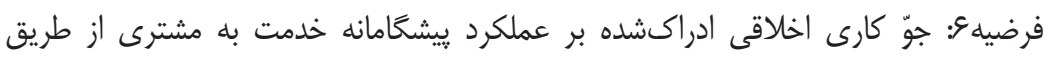

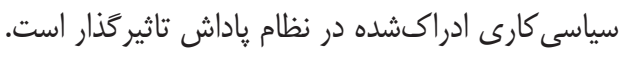

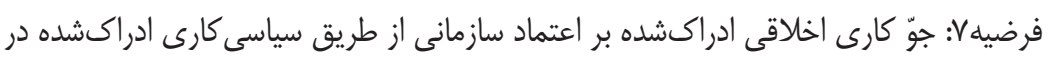

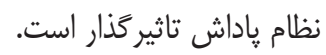

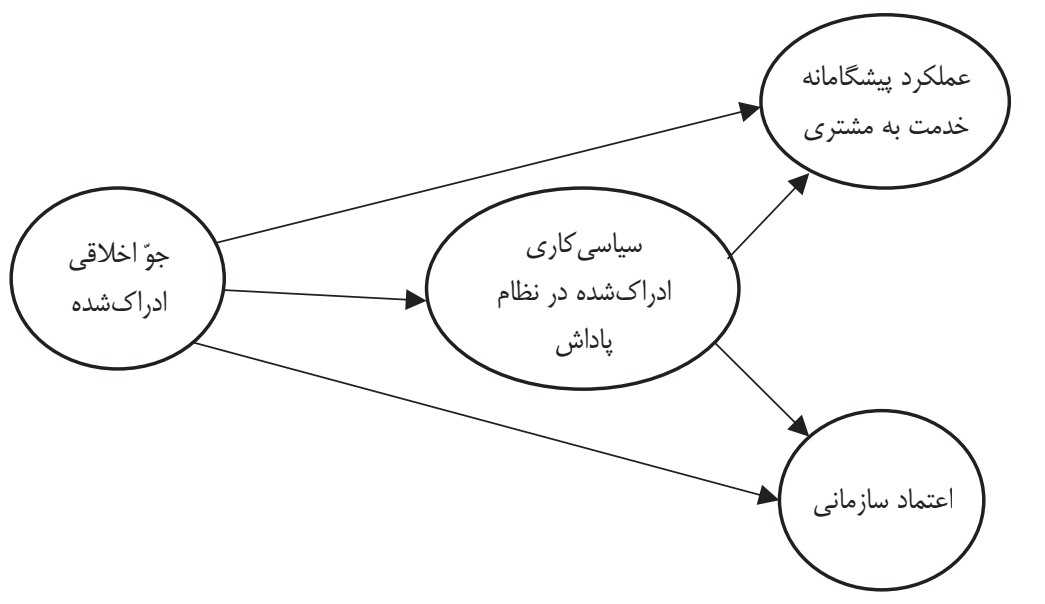

شكل 1: مدل مفهومى بزؤش بر اساس بزوهش (Lau et al., 2017)

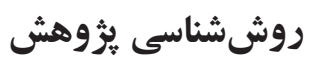

يزهش حاضر از لحاظ هدف، كاربردى و از لحاظ روش، توصيفى ـ ييمايشى است. جامعه آمارى

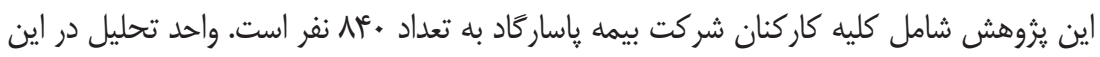

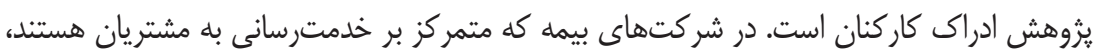
يبشگام بودن در ارائه خدمت به مشتريان ميتواند عامل مهمى براى موفقيت و كسب مزيت رقابتى

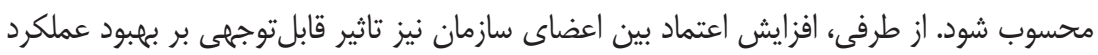

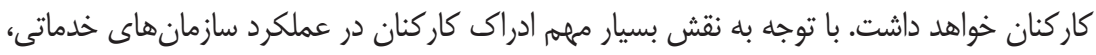
بررسى نقش ادراك كار كنان از جوّ اخلاقى سازمان و نيز ادراك از سياسى كارى در نظام ياداش شركت 
مى تواند نكتههاى ارزشمندى براى عملكرد بهتر شركت بيمه ياسار كاد فراهم سازد. در فر ايند يثوهش

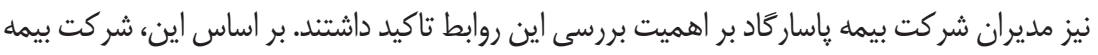

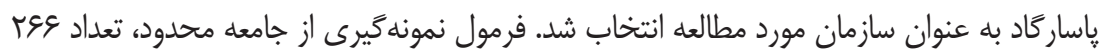

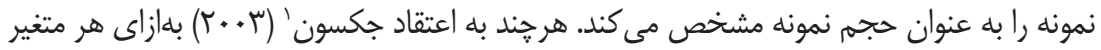

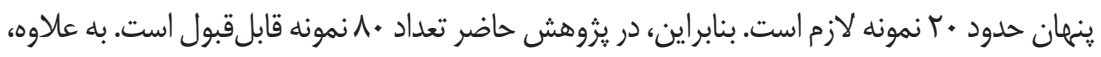

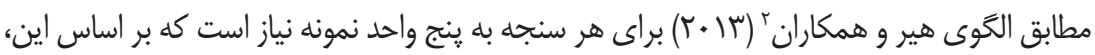

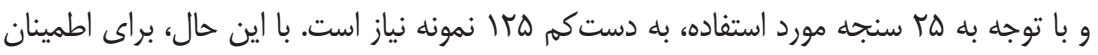

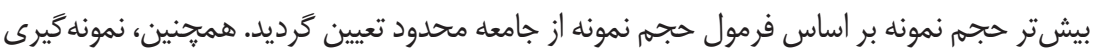

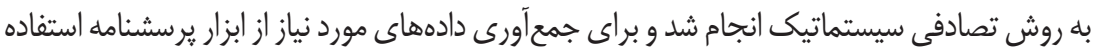

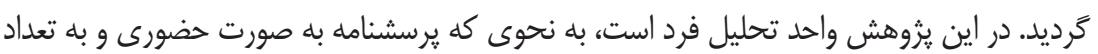

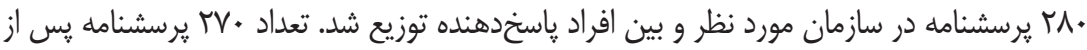

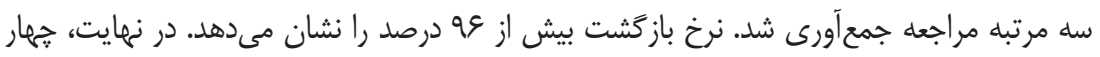

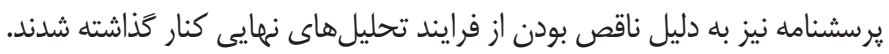

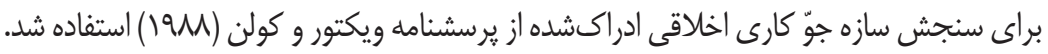

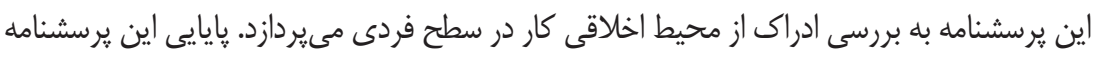

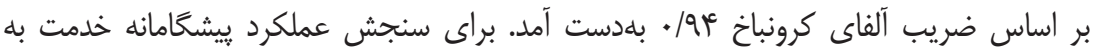

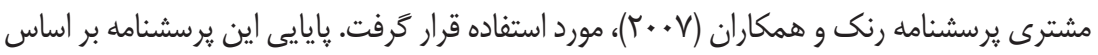

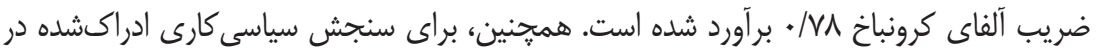

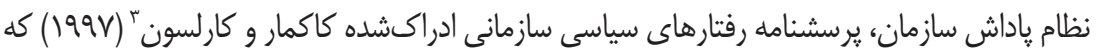

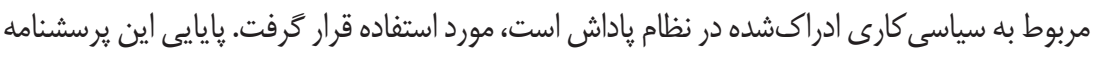

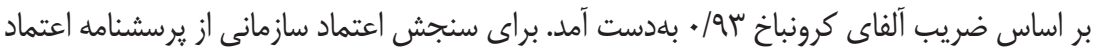

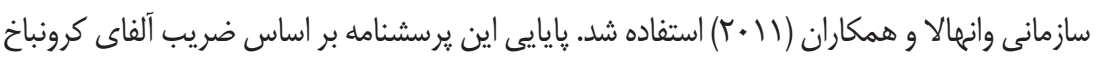

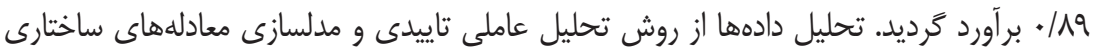

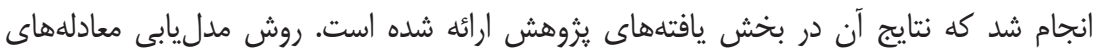

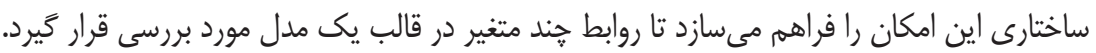

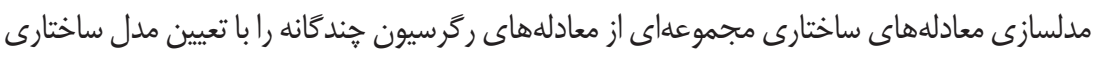

1. Jackson

2. Hair et al

3. Kacmar \& Carlson 
مورد استفاده بلطور همزمان ييشيينى مى كند. در تحليل عاملى تاييدى به بررسى روايى ابزار سنجش

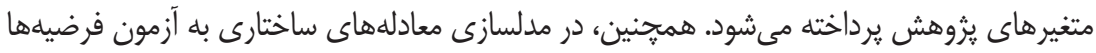

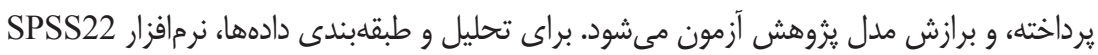
و براى تحليل عاملى و مدلسازى معادلههاى ساختارى، نرمافزار AMOS21 مورد استفاده قرار كرفت.

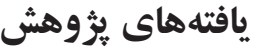

همانطور كه اشاره شد، نمونه آمارى يثوهش شامل عوب نفر از كار كنان شركت بيمه ياسار كاد

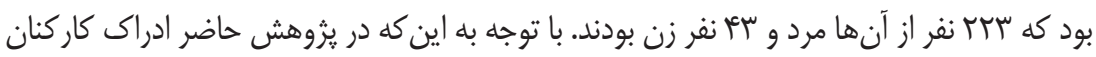

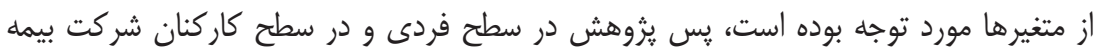

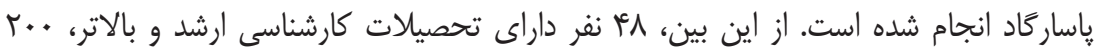

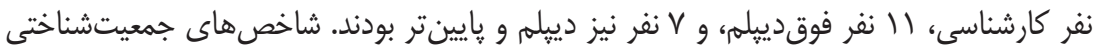

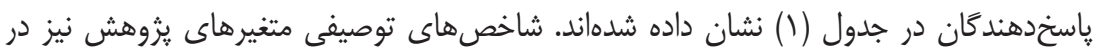

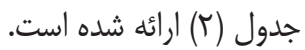

\begin{tabular}{|c|c|c|}
\hline rTr & زن & \multirow{2}{*}{ جنسيت } \\
\hline r & مرد & \\
\hline$\mu_{\Lambda}$ & كارشناسى ارشد و بالاتر & \multirow{4}{*}{ تحصيلات } \\
\hline r.. & كارشناسى & \\
\hline 11 & فوقدييلم & \\
\hline $\mathrm{v}$ & دييلم و بِايين تر & \\
\hline
\end{tabular}

\begin{tabular}{|c|c|c|c|c|}
\hline كشيدگى & جولخى & انحر اف استاندارد & ميانگين & 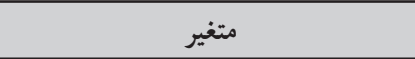 \\
\hline.$- / 1 Y \Lambda$ & $-1 / \Gamma 0$ & $1 / \cdot \mu^{r}$ & $r / \Lambda \Delta$ & جوُ كارى اخلاقى ادراكشده \\
\hline$r / 99$ & $-1 / 91$ & $\cdot / M \Lambda$ & $r / \cdot r$ & عملكرد بيشگامانه خدمت به مشترى \\
\hline$-\cdot / \Delta \Delta T$ & $1 / . \Delta r$ & $1 / \pi r$ & $r / r$ & سياسى كارى ادراكشده در نظام پاداش \\
\hline$-\cdot /$ TKT & $-1 / 1 T 4$ & $1 / \cdot v$ & $r / 94$ & اعتماد سازمانى \\
\hline
\end{tabular}


با توجه به شاخصهاى توصيفى مشاهده مىشود كه ميانخَين همه متغيرهاى بزوهش غير از

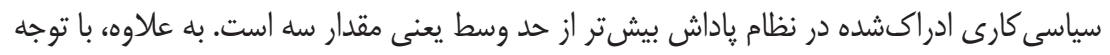

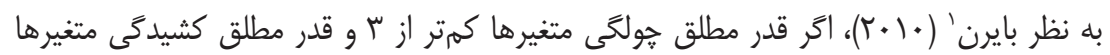

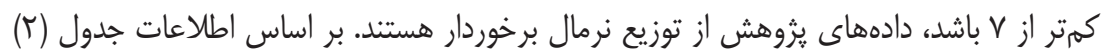

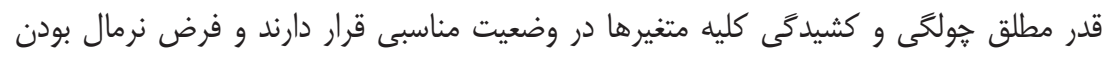

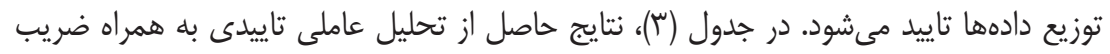

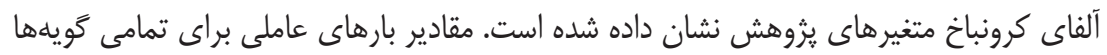

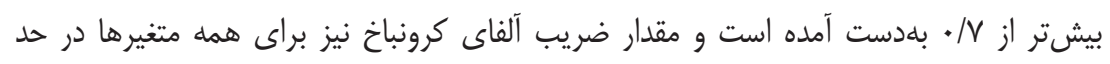

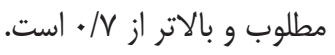

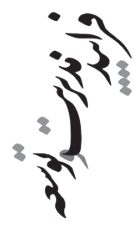

جدول بّ: يافتهاى تحليل عاملى تاييدى بثوهش

\begin{tabular}{|c|c|c|c|c|}
\hline $\begin{array}{l}\text { پايايى تر كيبى } \\
\text { (CR) }\end{array}$ & تبيينشده (AVE) & كرونباخ & بار عاملى گويهها & متغير \\
\hline$\cdot / 9$ & .190 & $\cdot / 9)^{4}$ & $\begin{array}{l}\cdot / \Lambda 1 \\
\cdot / 14 \\
\cdot / 10 \\
\cdot / \Lambda \cdot \\
\cdot / N 4 \\
\cdot / \Lambda \\
\cdot / A \\
\cdot / A \\
\cdot / N Q\end{array}$ & جوّ كارى اخلاقى ادراكشده \\
\hline •/Ar & $\cdot / 09$ & $\cdot / \mathrm{V} \wedge$ & $\begin{array}{l}\cdot / N T \\
\cdot / A I \\
\cdot / A r \\
\cdot / N V \\
\cdot / 99\end{array}$ & عملكرد بيشخامانه خدمت به مشترى \\
\hline
\end{tabular}

1. Byrne 
ادامه جدول بّ: يافتههاى تحليل عاملى تاييدى بزوهش

\begin{tabular}{|c|c|c|c|c|}
\hline $\begin{array}{l}\text { هايايى تركيبى } \\
\text { (CR) }\end{array}$ & تبيين شده (AVE) & كرونباخ & بار عاملى گويهها & متغير \\
\hline
\end{tabular}

$\cdot / \mathrm{AV}$

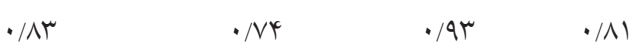

$\cdot / \mathrm{AV}$

سياسى كارى ادراكشده در

نظام پياداش ادراك

.$/ 91$

.$/ 94$

- /V

$\cdot / \wedge 9$

$\cdot / 09$

$\cdot / 19$

. /va

اعتماد سازمانى

$\cdot / 11$

$\cdot / 19$

با توجه به اطلاعات جدول (T) و جدول (r) و با توجه به مقدار مناسب شاخصهاى تناسب

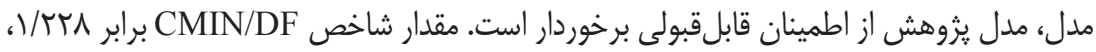

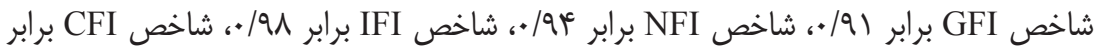
19 • و شاخص RMSEA برابر qج •/• بهدست آمده است. علاوه بر اين، بر اساس روش فورنل و

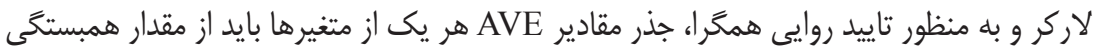
ميان آن متغير با ساير متغيرهاى مدل بيشتر باشد. در اين روش، ماتريسى محاسبه مىشود كه در

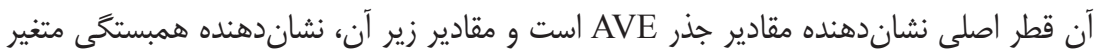
مربوطه با ساير متغيرهاست. جدول (أ) اين ماتريس را براى مدل يزوهش نشان مىدهد. 
جدول ث: روايى واكرا به روش فورنل و لار كر

\begin{tabular}{|c|c|c|c|c|}
\hline سازمانى اعتماد & سياسى كارى ادرى اكده در & بيشخامانه خدمت بـ بهرد & ادوّ كارى احلاقى & 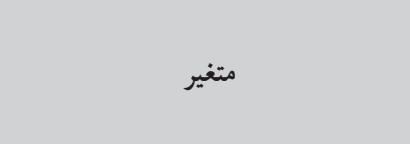 \\
\hline & & & $\cdot / 1 \cdot 9$ & جوّ كارى اخلاقى ادراكشده \\
\hline & & -/VGA & $\cdot 19 \wedge \mu$ & عملكرد يِيشگامانه خدمت به مشترى \\
\hline & •/Vq. & .1911 & .1910 & سياسى كارى ادراكشده در نظام پاداش \\
\hline •/VGA & $\cdot / \mathrm{NTI}$ & $\cdot / N r^{4}$ & $\cdot$ - VAY & اعتماد سازمانى \\
\hline
\end{tabular}

با توجه به جدول (أ) مشخص مىشود كه براى همه متغيرها، مقدار جذر AVE از ميزان همبستخى آن با ساير متغيرها كه در خانههاى زيرين و راست قطر اصلى نشان داده شدهاند،

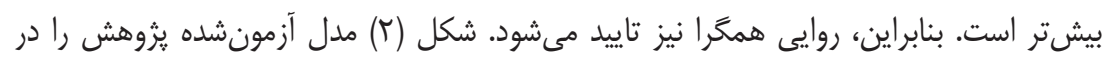
حالت استاندارد نشان مىدهد.
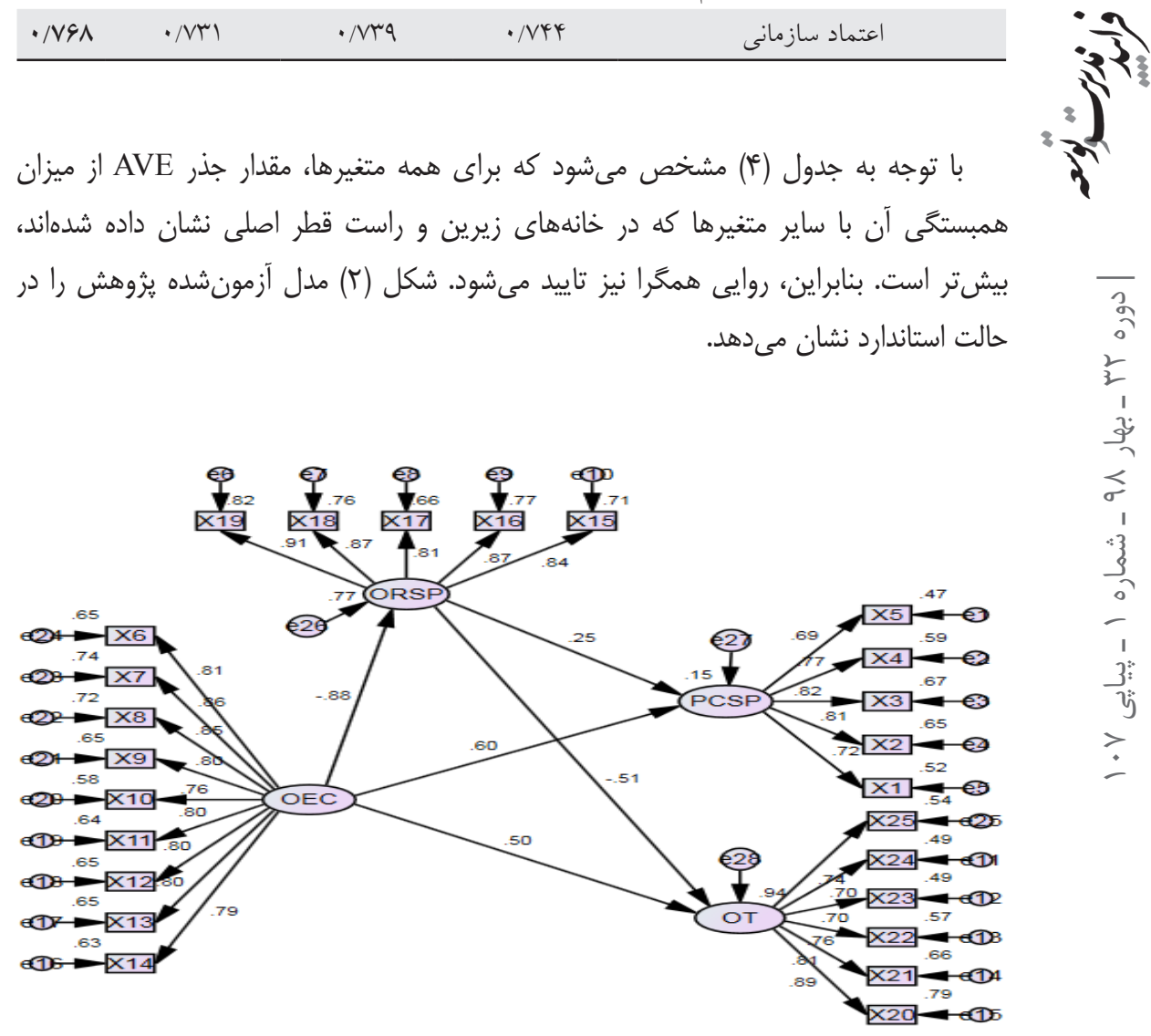

شكل r: مدل آزمونشده بزوهش

در پايان، نتايج آزمون فرضيههاى ڤزوهش در جدول (ه) ارائه شده است. 
جدول ه: نتايج آزمون فرضيههاى يزوهش

\begin{tabular}{|c|c|c|c|c|c|c|}
\hline نتيجه & كل & $\begin{array}{l}\text { اثر } \\
\text { P-value }\end{array}$ & $\begin{array}{c}\text { اثر غيرمستقيم } \\
\text { t-value P-value }\end{array}$ & t-value & $\begin{array}{l}\text { اثر مـ } \\
\text { P-value }\end{array}$ & فرضيه \\
\hline
\end{tabular}

جوّ كارى اخلاقى ادراكشده ـ

\begin{tabular}{|c|c|c|c|c|c|c|}
\hline 71 & & & & & & سياسى كارى ادراكشده در نظام پاداش \\
\hline lo/rVq & $\cdot /\left.\cdot\right|^{\circ \infty}$ & - & - & $-10 / r V q$ & $\cdot / \cdots 1^{m a s}$ & 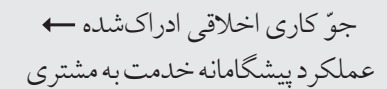 \\
\hline
\end{tabular}

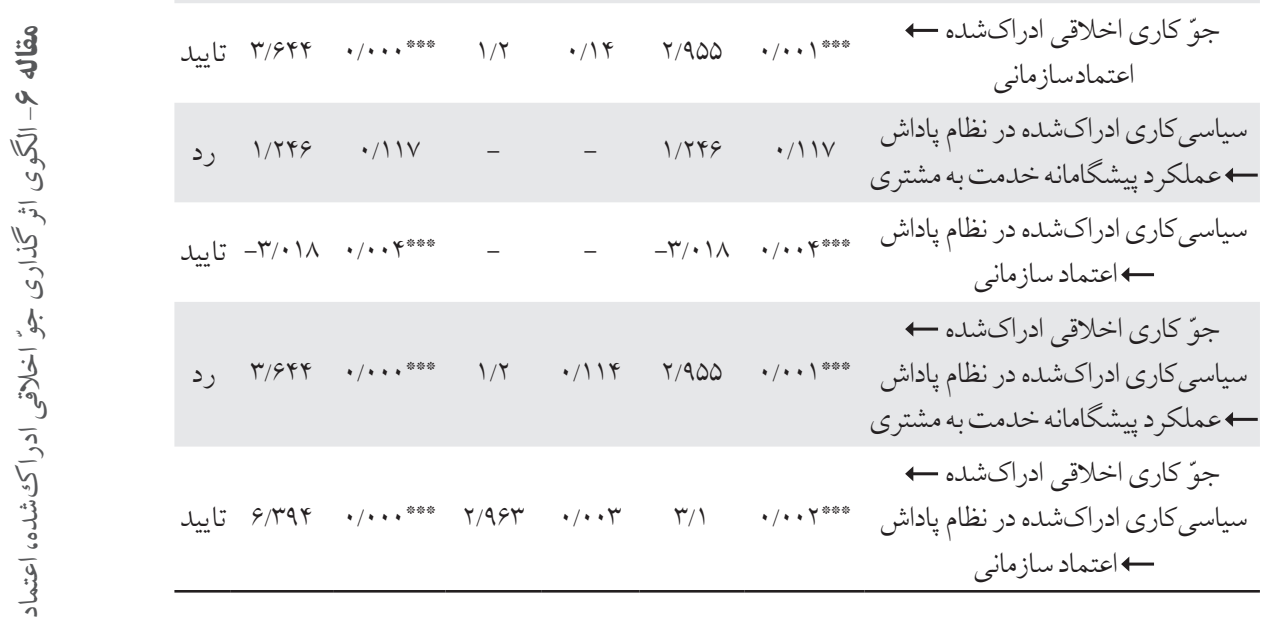

$* * *=\mathrm{P}<0 / 01$

علاوه بر اين، شاخصهاى برازش مدل آزمونشده نيز حاكى از برازش مطلوب مدل هستند.

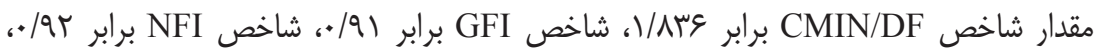

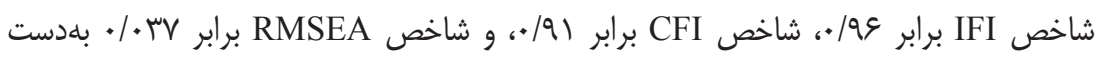

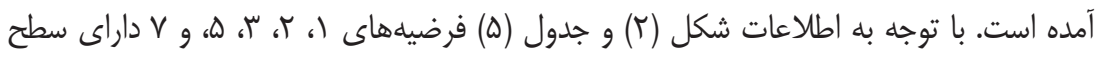

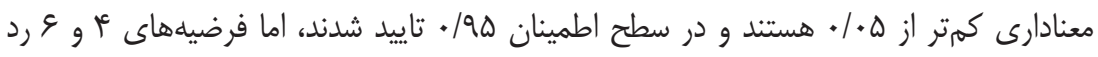

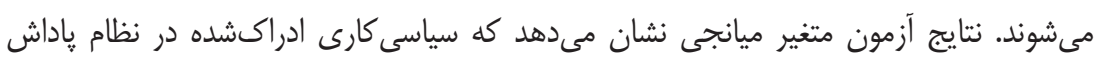

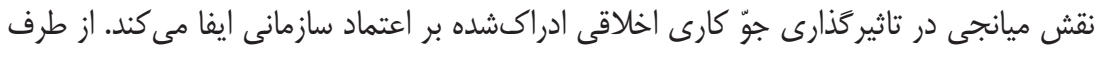

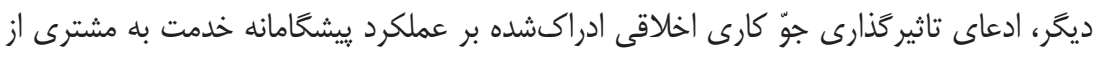
طريق سياسى كارى ادراكشده در نظام ياداش به دليل تاييد نشدن تاثير غيرمستقيه، حمايت نشد. 


\section{بحث و نتيجه كيرى}

هدف يزوهش حاضر بررسى تاثير جّ كارى اخلاقى ادراكشده بر اعتماد سازمانى و عملكرد

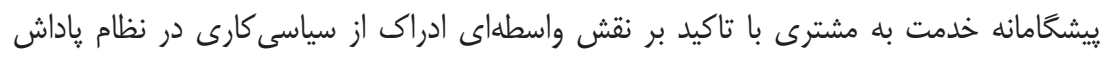

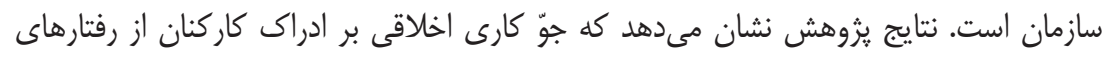

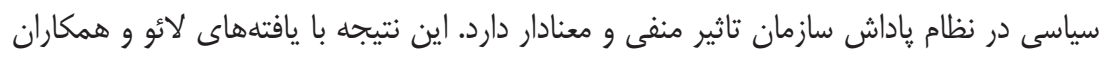

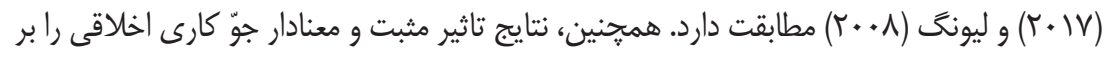

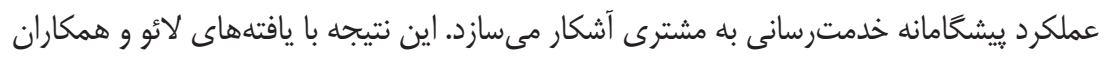

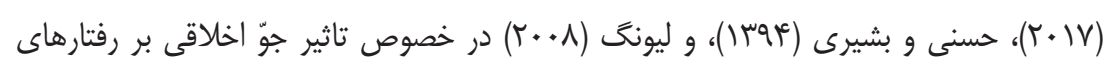

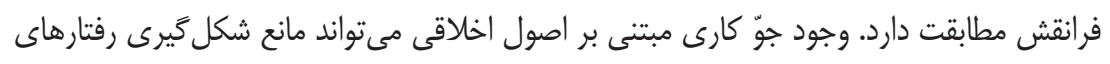

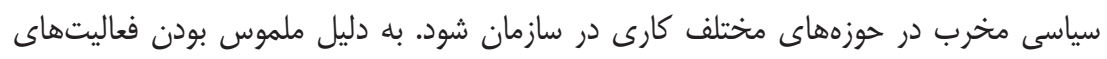

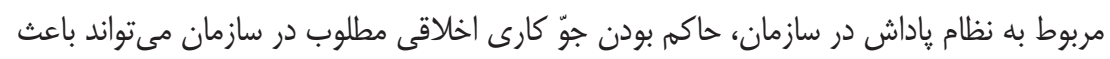

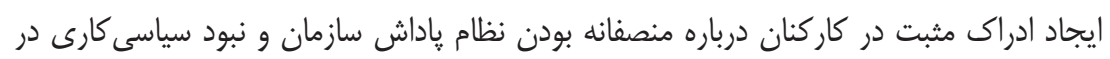

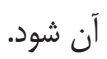

يافتهاى يزوهش نشان مىدهند كه جوّ كارى اخلاقى بر اعتماد سازمانى تاثير مثبت و

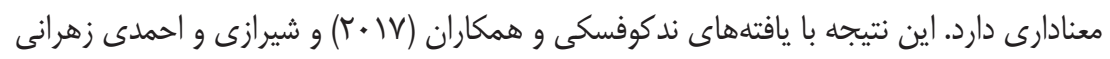

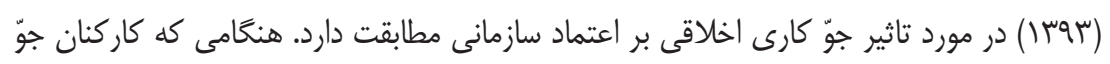

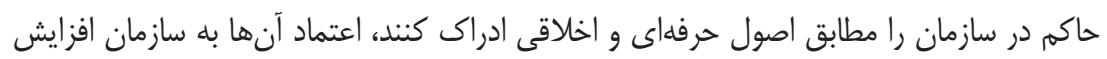

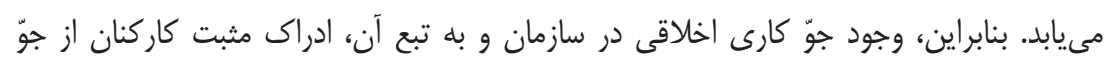

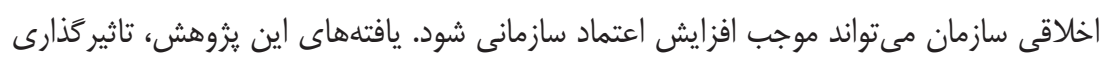

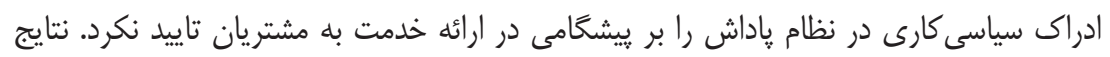

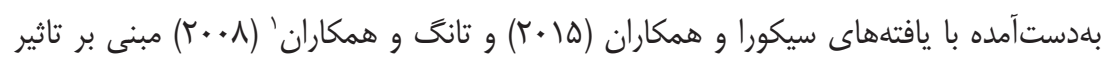

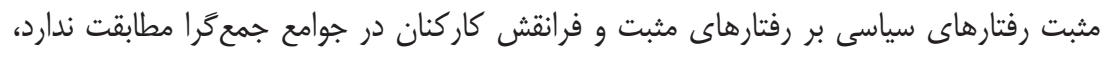

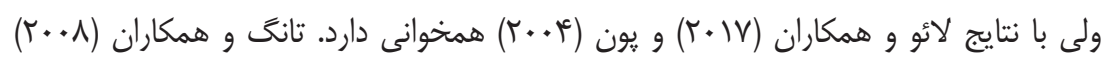

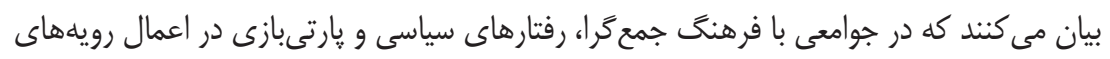

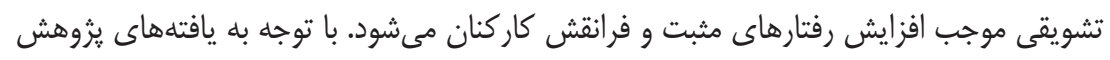

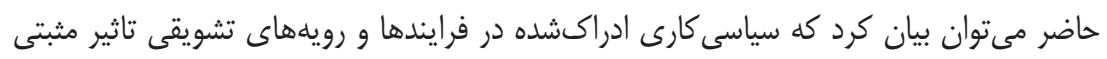

1. Tang et al 
بر بروز رفتارهاى مثبت و فرانقش كار كنان خدماتى ندارد، بلكه ممكن است كه به ادراك كاركنان

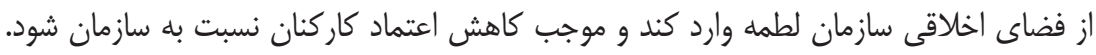
بنابراين، ييروى از فرايندها و رويههاى تشويقى سازمان به دور از جانبدارى مى تواند نتيجه مطلوبى براى سازمان در يى داشته باشد.

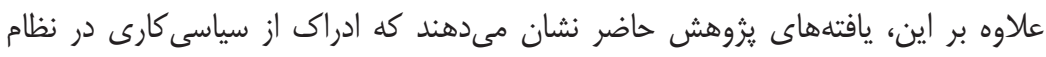

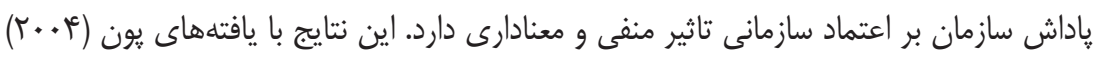

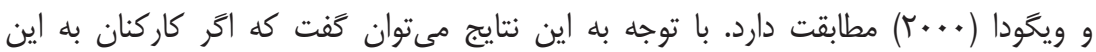

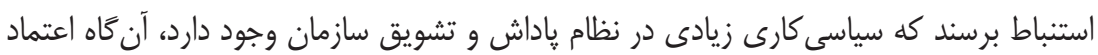

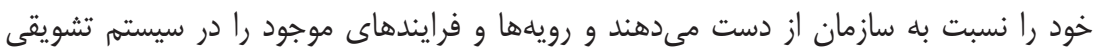
سازمان بى حاصل مىيندارند و ممكن است كه براى كسب نتايج دلخواه خودشان نيز دست بله

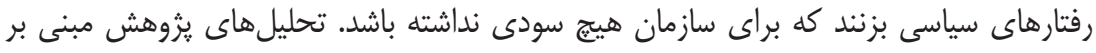

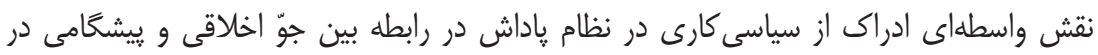

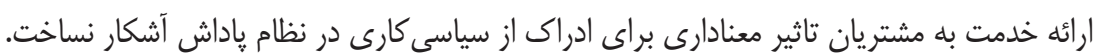

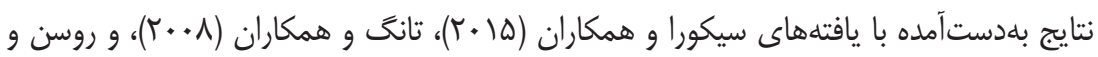

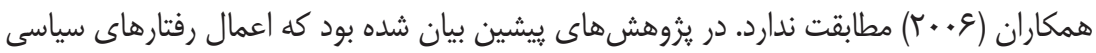

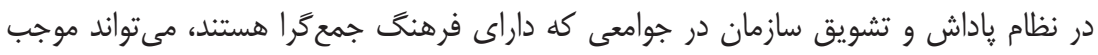

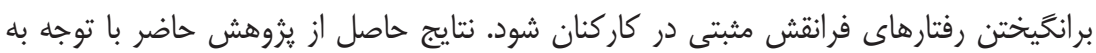

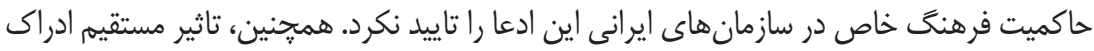

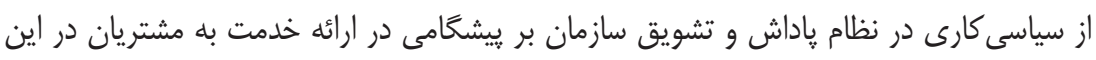

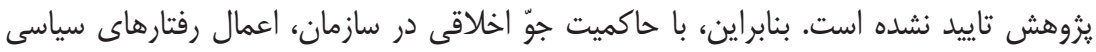

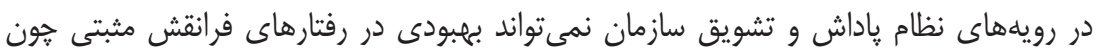
يشيشامى در ارائه خدمت به مشتريان ايجاد كند. همجنين، يافتههاى اين يزوهش نقش واسطهاى سياسى كارى ادراكشده را در نظام ياداش

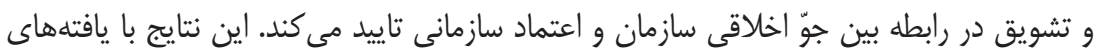

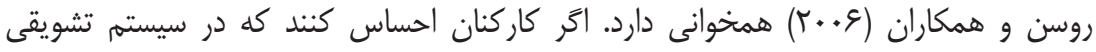

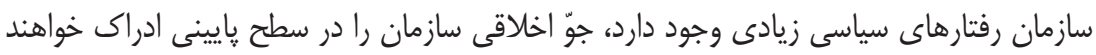

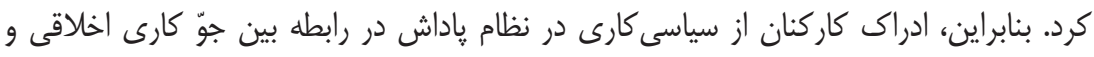

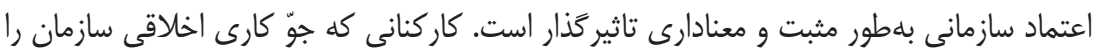


در سطح مطلوبى ادراك مى كنند، انتظار دارند كه اخلاق در تمامى رويهها و فرايندهاى سازمانى

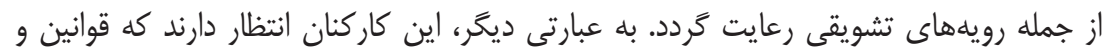

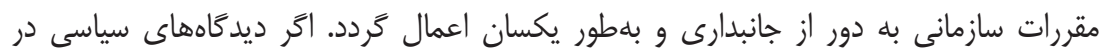

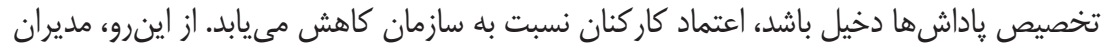

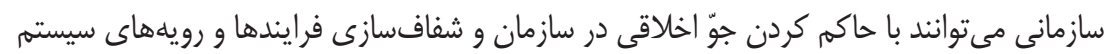

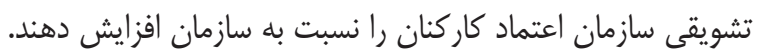

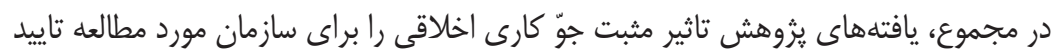

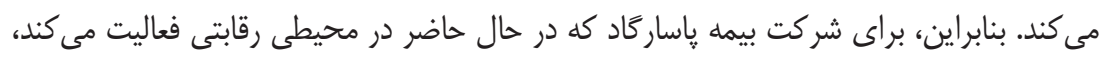

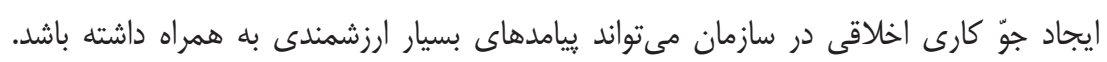

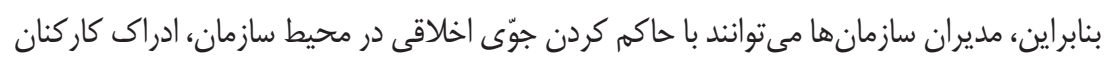

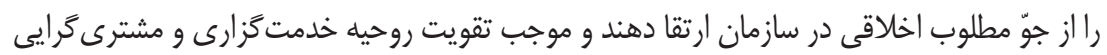

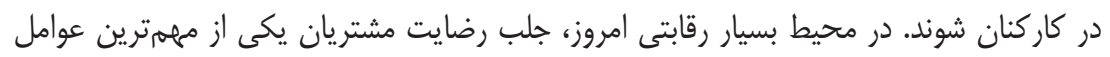

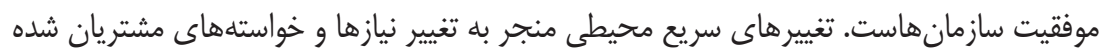

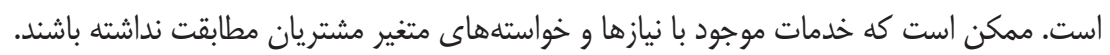

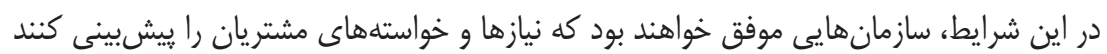

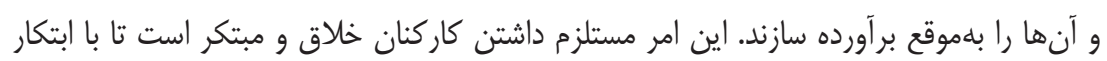

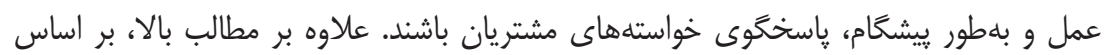

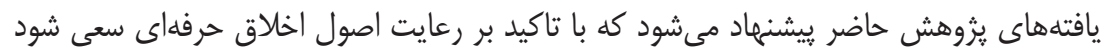

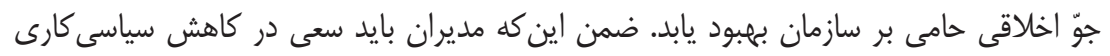

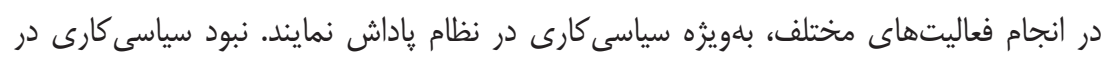

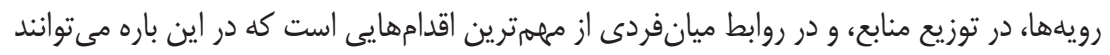

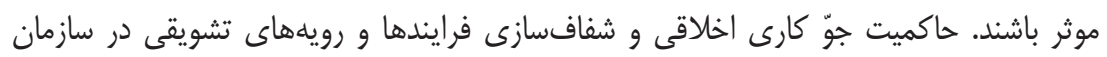

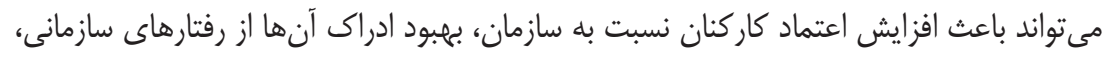

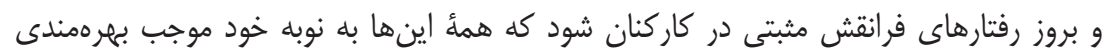

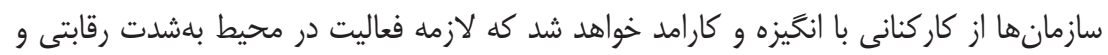
يوياى كنونى است. يزوهش حاضر به صورت مقطعى انجام شد و دادههاى آن صرفاً با يرسشنامه جمع آورى شدند

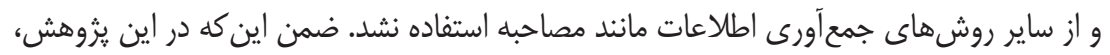


متغيرهاى مستقل، وابسته، و ميانجى در يك مقطع زمانى واحد و بر اساس نظر ياسخدهندًان

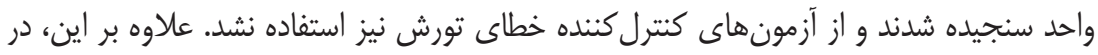
يزوهش حاضر تاثير برخى از متغير ها مانند سن، جنسيت، سطح تحصيلات، سابقه كار، و نوع شغل افراد در واحد سازمانى كه ممكن بود بر نتايج يزوهش موثر باشند، كنترل نشدند. بر اساس اين آنسان

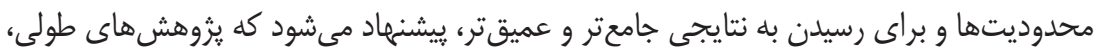
با استفاده از روشهاى كمّى، كيفى، و تركيبى و در ساير سازمان هاى خدماتى انجام شود. به علاوه،

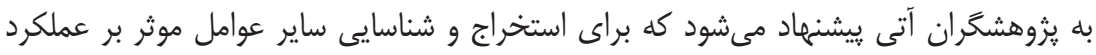

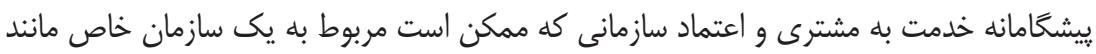
يك شركت بيمه باشند، يزوهشهاى اكتشافى انجام شود. در اين بين، توجه به متغيرهايى مانند النا

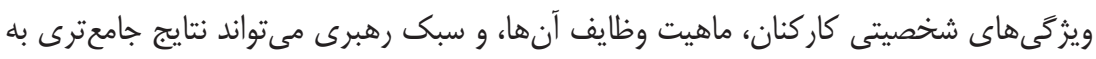
همراه داشته باشد.

\section{منابع}

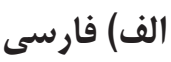

حسنى، محمد، و بشيرى، زينا (أوب(1). رابطه جوّ اخلاقى با يِامدهاى مثبت و منفى سازمانى. فصلنامه

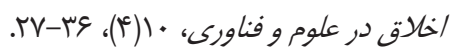

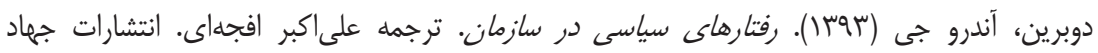
دانشخاهى، واحد دانشخاه علامه طباطبايى.

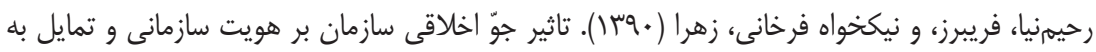

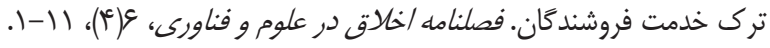

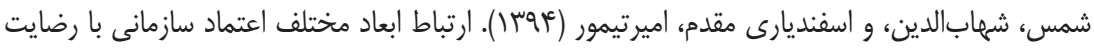

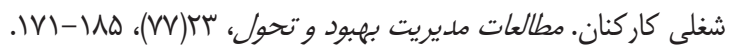

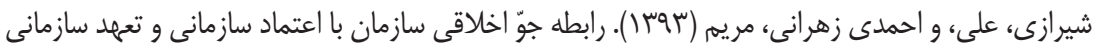

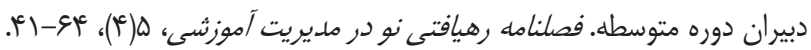

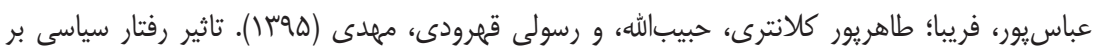

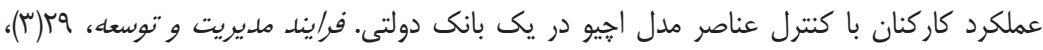

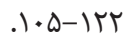

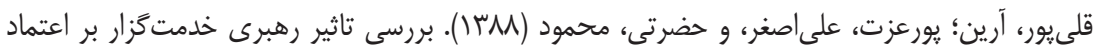

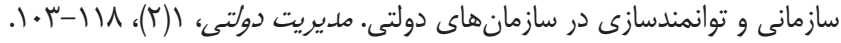




$$
\begin{aligned}
& \text { مقيمى، سيدمحمد (سوسا). مبانى سازمان و مديريت. انتشارات نخاه دانش. }
\end{aligned}
$$

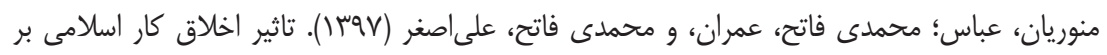

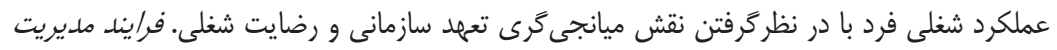

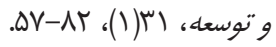

\section{ب) انخَليسى}

Adams, J. S., Tashchian, A., \& Shore, T. H. (2001). Codes of ethics as signals for ethical behavior. Journal of Business ethics, 29(3), 199-211.

Altuntas, M., \& Rauch, J. (2017). Concentration and financial stability in the property-liability insurance sector: global evidence. The Journal of Risk Finance, 18(3), 284-302.

Appelbaum, S. H., Deguire, K. J., \& Lay, M. (2005). The relationship of ethical climate to deviant workplace behaviour. Corporate Governance: The international journal of business in society, 5(4), 43-55.

Aryee, S., Chen, Z. X., \& Budhwar, P. S. (2004). Exchange fairness and employee performance: An examination of the relationship between organizational politics and procedural justice. Organizational behavior and human decision processes, 94(1), 1-14.

Boon, C., \& Kalshoven, K. (2014). How high-commitment HRM relates to engagement and commitment: The moderating role of task proficiency. Human Resource Management, 53(3), 403-420.

Bowen, D. E. (2016). The changing role of employees in service theory and practice: An interdisciplinary view. Human Resource Management Review, 26(1), 4-13.

Bowler, W. M., Halbesleben, J. R., \& Paul, J. R. (2010). If you're close with the leader, you must be a brownnose: The role of leader-member relationships in follower, leader, and coworker attributions of organizational citizenship behavior motives. Human Resource Management Review, 20(4), 309-316.

Byrne, B. M. (2010) Structural Equation Modeling with AMOS: Basic Concepts, Applications \& Programming. $2^{\text {nd }}$ edition, New York: Taylor \& Francis Group.

Chang, J., O’Neill, G., \& Travaglione, A. (2016). Demographic influences on employee trust towards managers. International Journal of Organizational Analysis, 24(2), 246-260.

Dickson, M. W., Smith, D. B., Grojean, M. W., \& Ehrhart, M. (2001). An organizational climate regarding ethics: The outcome of leader values and the practices that reflect them. The Leadership Quarterly, 12(2), 197-217. 
Ellinger, A. E., Keller, S. B., \& Baş, A. B. E. (2010). The empowerment of frontline service staff in 3PL companies. Journal of Business Logistics, 31(1), 79-98.

Emamgholipour, S., Arab, M., \& Mohajerzadeh, Z. (2017). Life insurance demand: middle East and North Africa. International Journal of Social Economics, 44(4), 521-529.

Fortin, M., \& Fellenz, M. R. (2008). Hypocrisies of fairness: Towards a more reflexive ethical base in organizational justice research and practice. Journal of Business ethics, 78(3), 415-433.

Fulmer, C. A., \& Gelfand, M. J. (2012). At what level (and in whom) we trust: Trust across multiple organizational levels. Journal of management, 38(4), 1167-1230.

Gorostidi-Martinez, H., \& Zhao, X. (2017). Corporate political strategies: a contemporary literature review. Journal of Advances in Management Research, 14(3), 375-404.

Gotsis, G. N., \& Kortezi, Z. (2010). Ethical considerations in organizational politics: Expanding the perspective. Journal of Business ethics, 93(4), 497-517.

Grant, A. M., \& Ashford, S. J. (2008). The dynamics of proactivity at work. Research in organizational behavior, 28(1), 3-34.

Griep, Y., \& Vantilborgh, T. (2018). Reciprocal effects of psychological contract breach on counterproductive and organizational citizenship behaviors: The role of time. Journal of Vocational behavior, 104(1), 141-153.

Griffin, M. A., Neal, A., \& Parker, S. K. (2007). A new model of work role performance: Positive behavior in uncertain and interdependent contexts. Academy of management journal, 50(2), 327-347.

Hair, J. F., Black, W. C., Babin, B. J., \& Anderson, R. E. (2013). Multivariate data analysis: Pearson new international edition: Pearson Higher Ed.

Hofstede, G. H. (2001). Culture's consequences: comparing values, behaviors, institutions and organizations across nations. Sage: Thousand Oaks, CA.

Hsiung, H. H., Lin, C. W., \& Lin, C. S. (2012). Nourishing or suppressing? The contradictory influences of perception of organizational politics on organizational citizenship behaviour. Journal of Occupational and Organizational Psychology, 85(2), 258-276.

Hu, X., \& Jiang, Z. (2018). Employee-oriented HRM and voice behavior: a moderated mediation model of moral identity and trust in management. The International Journal of Human Resource Management, 29(5), 746-771.

Jackson, D. L. (2003). Revisiting sample size and number of parameter estimates: Some support for the N: q hypothesis. Structural equation modeling, 10(1), 128-141. 
Kacmar, K. M., \& Carlson, D. S. (1997). Further validation of the perceptions of politics scale (POPS): A multiple sample investigation. Journal of management, 23(5), 627-658.

Lau, P. Y. Y., Tong, J. L. T., Lien, B. Y.-H., Hsu, Y.-C., \& Chong, C. L. (2017). Ethical work climate, employee commitment and proactive customer service performance: Test of the mediating effects of organizational politics. Journal of Retailing and Consumer Services, 35(1), 20-26.

Lee, S. M., Lee, D., \& Kang, C.-Y. (2012). The impact of high-performance work systems in the health-care industry: employee reactions, service quality, customer satisfaction, and customer loyalty. The Service Industries Journal, 32(1), 17-36.

Leung, A. S. (2008). Matching ethical work climate to in-role and extra-role behaviors in a collectivist work setting. Journal of Business ethics, 79(1-2), 43-55.

Li, Y., Chen, M., Lyu, Y., \& Qiu, C. (2016). Sexual harassment and proactive customer service performance: The roles of job engagement and sensitivity to interpersonal mistreatment. International Journal of Hospitality Management, 54(1), 116-126.

Lyu, Y., Zhou, X., Li, W., Wan, J., Zhang, J., \& Qiu, C. (2016). The impact of abusive supervision on service employees' proactive customer service performance in the hotel industry. International Journal of Contemporary Hospitality Management, 28(9), 1992-2012.

Martin, K. D., \& Cullen, J. B. (2006). Continuities and extensions of ethical climate theory: A meta-analytic review. Journal of Business ethics, 69(2), 175-194.

Nedkovski, V., Guerci, M., De Battisti, F., \& Siletti, E. (2017). Organizational ethical climates and employee's trust in colleagues, the supervisor, and the organization. Journal of Business Research, 71(1), 19-26.

Poon, J. M. (2004). Effects of performance appraisal politics on job satisfaction and turnover intention. Personnel review, 33(3), 322-334.

Rank, J., Carsten, J. M., Unger, J. M., \& Spector, P. E. (2007). Proactive customer service performance: Relationships with individual, task, and leadership variables. Human Performance, 20(4), 363-390.

Raub, S., \& Liao, H. (2012). Doing the right thing without being told: Joint effects of initiative climate and general self-efficacy on employee proactive customer service performance. Journal of applied psychology, 97(3), 651-667.

Rosen, C. C., Levy, P. E., \& Hall, R. J. (2006). Placing perceptions of politics in the context of the feedback environment, employee attitudes, and job performance. Journal of applied psychology, 91(1), 211-220. 
Salamon, T., Milfelner, B., \& Belak, J. (2017). Ethical culture as a predictor of late payments. Kybernetes, 46(4), 621-637.

Shao, R., Rupp, D. E., Skarlicki, D. P., \& Jones, K. S. (2013). Employee justice across cultures: A meta-analytic review. Journal of management, 39(1), 263-301.

Sikora, D. M., Ferris, G. R., \& Van Iddekinge, C. H. (2015). Line manager implementation perceptions as a mediator of relations between highperformance work practices and employee outcomes. Journal of applied psychology, 100(6), 1908-1918.

Simha, A., \& Stachowicz-Stanusch, A. (2015). The effects of ethical climates on trust in supervisor and trust in organization in a Polish context. Management decision, 53(1), 24-39.

Taamneh, A., Alsaad, A. K., \& Elrehail, H. (2018). HRM practices and the multifaceted nature of organization performance: The mediation effect of organizational citizenship behavior. EuroMed Journal of Business, 13(3), 315-334.

Tang, T. L.-P., Sutarso, T., Davis, G. M.-T. W., Dolinski, D., Ibrahim, A. H. S., \& Wagner, S. L. (2008). To help or not to help? The Good Samaritan Effect and the love of money on helping behavior. Journal of Business ethics, 82(4), 865-887.

Vanhala, M., Puumalainen, K., \& Blomqvist, K. (2011). Impersonal trust: The development of the construct and the scale. Personnel review, 40(4), 485-513.

Victor, B., \& Cullen, J. B. (1988). The organizational bases of ethical work climates. Administrative science quarterly, 33(1), 101-125.

Vigoda, E. (2000). Organizational politics, job attitudes, and work outcomes: Exploration and implications for the public sector. Journal of Vocational behavior, 57(3), 326-347. 